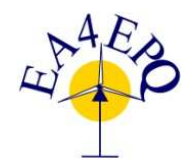

International Conference on Renewable Energies and Power Quality (ICREPQ'13)

Bilbao (Spain), 20 th $22^{\text {th }}$ March, 2013

Renewable Energy and Pourer Qualily. Fournal (RE\&PQJ)

ISSN 2172-038 X, No.11, March 2013

\title{
Performance prediction of a solar hot water system with change of circulating pump efficiency in solar collectors
}

\author{
Youn Cheol Park, Le Minh Nhut \\ Department of Mechanical Engineering \\ Jeju National University \\ 1, Ara Dong, Jeju City, Jeju Do, 690756 (Korea) \\ Phone number:+82 64754 3626, e-mail: ycpark@jejunu.ac.kr, nhutlm@jejunu.ac.kr
}

\begin{abstract}
In this study a mathematical model was developed to predict operating performance of the solar collector under specified weather conditions at Jeju Island, Korea. The optimum mass flow rate through collector based on the relationship between the useful heat gain of solar collector and the electricity consumption of solar pump is investigated. Besides, the effect of various parameters such as solar collector area, initial water temperature and volume of storage tank is analyzed. The results of the simulation show that the system performance increased about $1.33 \%$ at $m=0.442 \mathrm{~kg} / \mathrm{s}$ with the new coefficient $K_{c}=0.17$.

Furthermore the system performance is affected strongly by the change of collector area, initial water temperature and volume of storage tank

It should give concise information on the aims, the methods, the results and the conclusions of the paper. Its length should not exceed 200 words.
\end{abstract}

\section{Key words}

collector; solar domestic hot water; mass flow rate; electricity consumption of solar pump

\section{Introduction}

The performance of solar collector is an important factor of solar thermal system which is mainly influenced by mass flow rate through collector. There was a series of studies on this issue in a long time. An optimal control mass flow rate through solar collector, thus allowing the useful heat gain of collectors to increase when the amount of solar radiation is low, whereas reducing the energy consumption for pumping are reported in Refs. [2-7]. All the solutions given above the papers could not be applied to control solar pump because the optimal controller was not a function of measurable states of the system and it required prior knowledge of the solar radiation and the ambient temperature. Recently, in 2005, Persson and Ronnelid, proposed a method of determining the mass flow rate used for the collector circuit based on the relations with the collector area.(see Ref. [16]). However, this proposition is not in good agreement with all the cases. In this paper, the solution of Persson and Ronnelid has been extended and modified to predict the system performance by a simplified mathematical model. In addition, the effect of a various parameters is considered.
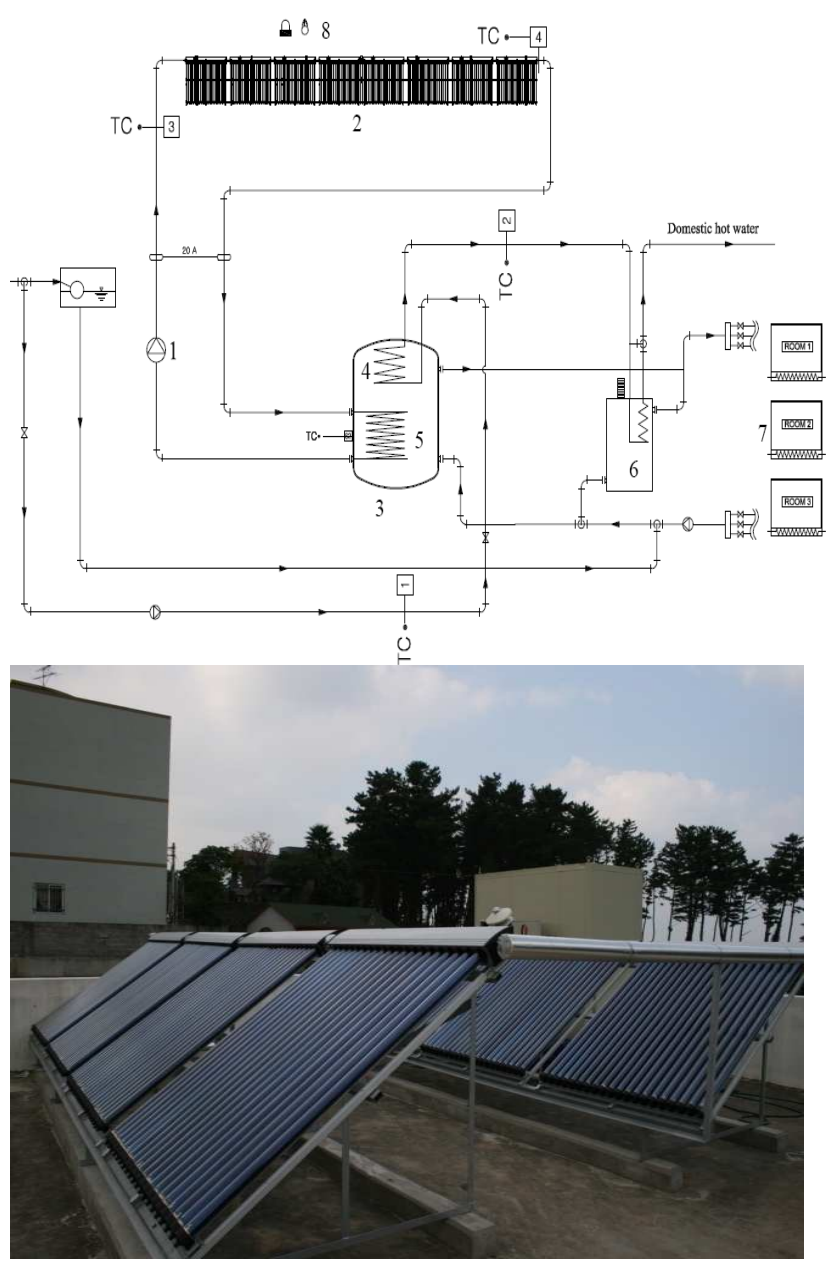

Fig. 1. Schematic diagram of the solar collector domestic hot water system: (1) Solar pump, (2) Solar collector, (3) storage tank, (4) internal heat exchanger of domestic hot water, (5) internal heat exchanger of collector circuit, (6) boiler, (7) panel heating, (8) pyranometer and ambient air temperature sensor.

\section{System description}


The schematic diagram of the solar collector domestic hot water system is shown in Fig. 1. It consists of a few main components such as: solar collector, storage tank, boiler, panel heating and personal computer. The vacuum tube solar collector panels has the total collection surface area is $A_{c}=26 \mathrm{~m}^{2}$. The storage tank has a capacity $1200 \mathrm{~L}$. It is the vertical type, made of stainless, with an internal height of $1.8 \mathrm{~m}$. A value of heat transfer coefficient between the water in the tank and air in the room is $U_{s}=0.33 \mathrm{~W} /\left(m^{2} K\right)$ [7], which is adopted in Eq. (8).

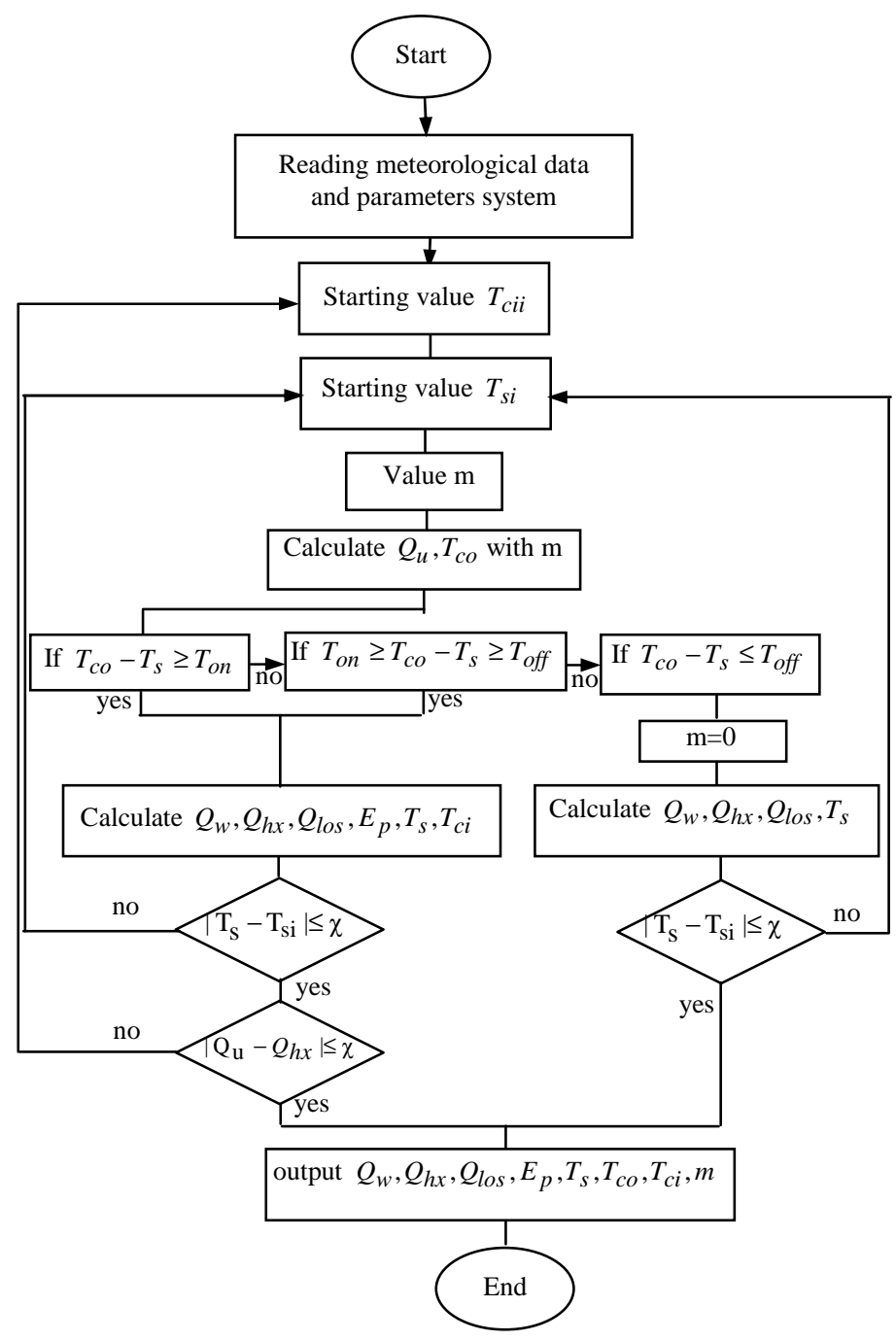

Fig. 2. Flow chart of the proposed program.

\section{Mathematical Model}

The assumption that the heat loss on the pipe connect of collector and storage tank is neglected so that water temperature at solar collector inlet equal the water temperature at the exit of the internal heat exchanger of solar collector in tank and is given by:

$$
\mathrm{T}_{\mathrm{ci}}=\left(\mathrm{T}_{\mathrm{co}}-\mathrm{T}_{\mathrm{s}}\right) \cdot \exp \left(\frac{-\mathrm{U}_{1} \cdot \mathrm{A}_{1}}{\mathrm{~m} \cdot \mathrm{c}_{\mathrm{p}}}\right)+\mathrm{T}_{\mathrm{S}}
$$

Where $A_{1}$ and $U_{1}$ are the heat transfer surface area and overall heat coefficient of internal exchanger solar collector, respectively. The mass flow rate of the collector circuit calculated [16] by:

$$
\mathrm{m}=\left(\mathrm{K}_{\mathrm{c}} \cdot \frac{\mathrm{A}_{\mathrm{c}}}{10}\right),(\mathrm{kg} / \mathrm{s})
$$

Where $K_{c}$ proposed [16] is $K_{c}=0.14$. In this work, a new coefficient $K_{c}$ obtained from simulation program is adopted to calculate and the result shown in section 4 below.

The electricity consumption of solar pump calculated [7] by:

$$
E_{p}=K_{p} \cdot m^{3}
$$

An energy balance on the fully mixed water storage tank is expresses as:

$$
\mathrm{C}_{\mathrm{t}} \cdot \frac{\mathrm{dT}_{\mathrm{S}}}{\mathrm{dt}}=\mathrm{Q}_{\mathrm{u}}-\mathrm{Q}_{\mathrm{w}}-\mathrm{Q}_{\mathrm{st}}
$$

Where $C_{t}=M . c_{p}, T_{s}$ are the heat capacity and the temperature of water in the storage tank, respectively. In addition, the heat loss of storage tank given by:

$$
\mathrm{Q}_{\mathrm{st}}=\mathrm{U}_{\mathrm{s}} \cdot \mathrm{A}_{\mathrm{s}}\left(\mathrm{T}_{\mathrm{s}}-\mathrm{T}_{\mathrm{a}}\right)
$$

Where $A_{s}, U_{s}$ are the surface area of storage tank and the heat transfer coefficient between the water in tank and the air in the room where storage tank is locates.

The heat flux $Q_{w}$ delivered from storage tank transferred to user expressed as:

$$
Q_{w}=m_{w} \cdot c_{p}\left(T_{s}-T_{w i}\right)\left[1-\exp \left(-\frac{U_{w} \cdot A_{w}}{m_{w} \cdot c_{p}}\right)\right]
$$

Where $T_{w i}, m_{w}$ are the fresh water temperature and mass flow rate hot water delivered to user, respectively, and $A_{w}$ and $U_{w}$ are the heat transfer surface area and the overall heat coefficient of internal heat exchanger of domestic hot water, respectively. In this study, $m_{w}, T_{w i}$ are given by input data.

The heat flux of solar collector transferred to storage tank calculated as follows:

$$
Q_{h x}=U_{1} \cdot A_{1} \cdot \Delta T_{l m}
$$

Here, $\Delta T_{l m}$ is log mean temperature difference at internal exchanger solar collector.

From mathematical model was mentioned above, a MATLAB program is written and developed to simulate for the proposed system. The flow chart of the calculation program is shown in Fig. 2.

\section{Results and discussion}

Fig. 3 (a) shows a schematic relationship of both the useful heat gain $Q_{u}$ and electricity consumption $\mathrm{E}_{\mathrm{p}}$ as functions of mass flow rate (coefficient $\mathrm{K}_{\mathrm{c}}$ ) on the during a day time. The value of optimal mass flow rate is determined at the point where the distance between the two curves is the greatest. In this work, the optimal of the mass flow rate at $m=0.442 \mathrm{~kg} / \mathrm{s}$ corresponds with coefficient $\mathrm{K}_{\mathrm{c}}=0.17$ is chosen. Another reason to choose the coefficient, at the backward coefficients of $\mathrm{K}_{\mathrm{c}}=0.17$, the amount of useful heat gain $Q_{u}$ increased faster than 
(a)
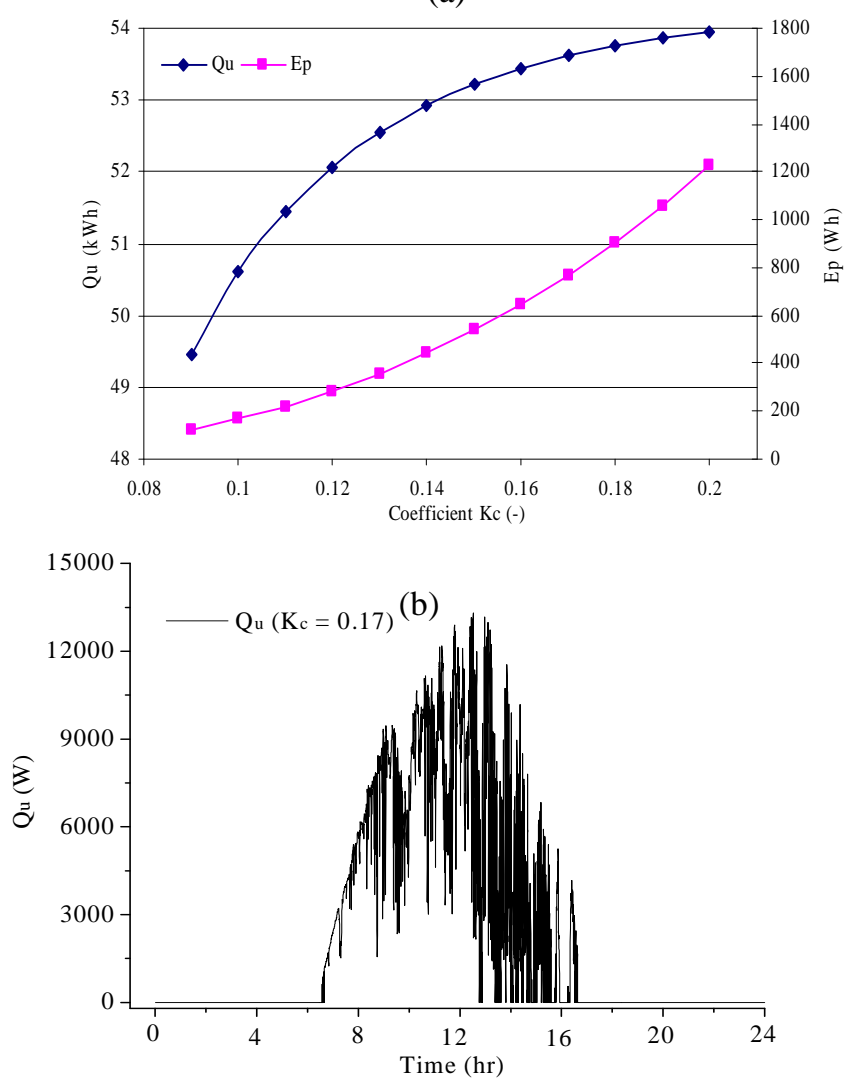

Fig. 3. (a) Effect of coefficient $K_{c}$ on the useful heat gain $Q_{u}$ and electricity consumption $E_{p}$ during a day time; (b) the useful heat gain $Q_{u}$ supplied to storage tank on the hour of the day.
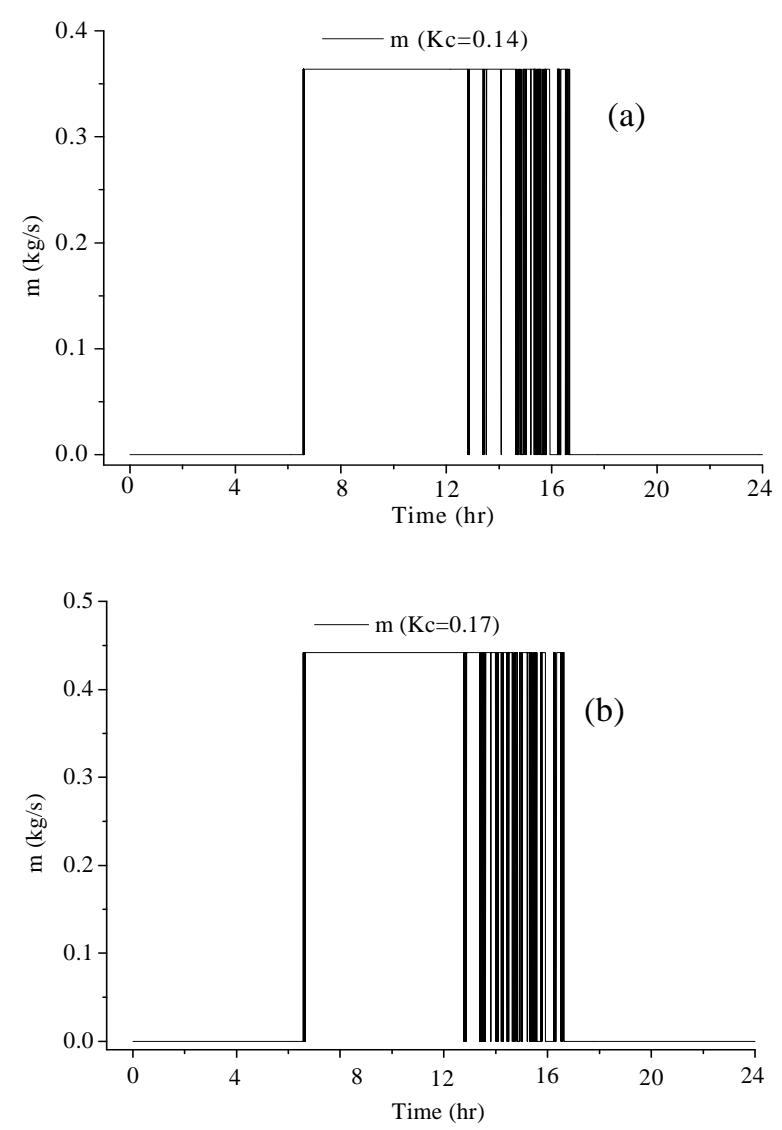

Fig. 4. Mass flow rate $\mathrm{m}(\mathrm{kg} / \mathrm{s})$ on the hour of the day, (a) $m=0.364\left(K_{c}=0.14\right) \mathrm{kg} / \mathrm{s} ;\left(\right.$ b) $m=0.442\left(K_{c}=0.17\right) \mathrm{kg} / \mathrm{s}$.


Fig. 5. (a) The temperature of water in the storage tank and (b) heat loss of storage tank on the hour of the day.

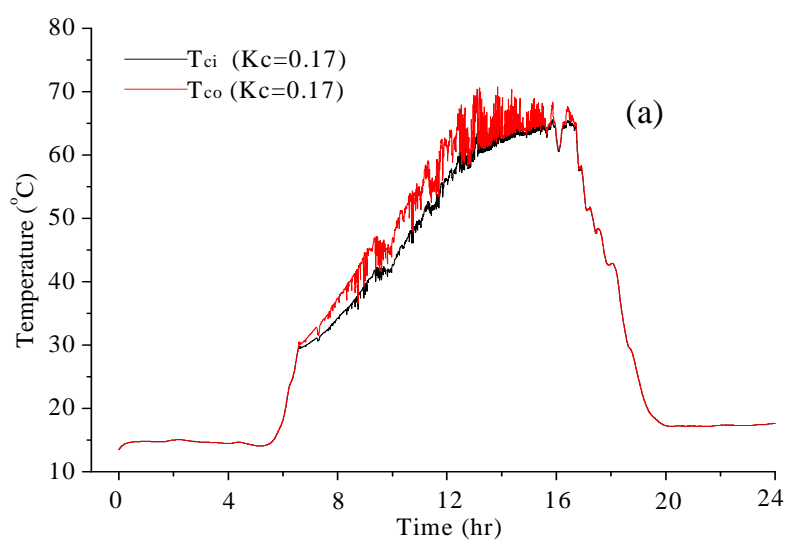

(b)

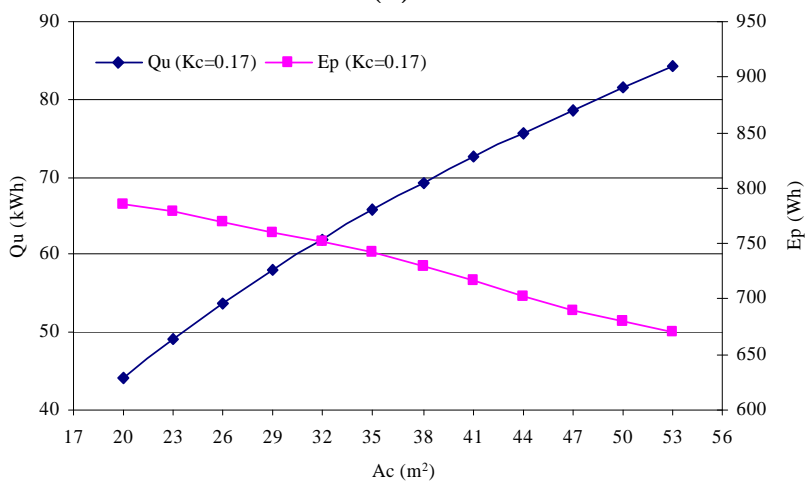

Fig. 6. (a) Inlet and outlet water temperature of collector on the hour of the day; (b) effect of collector area with respect to the useful heat gain $Q_{u}$ and electricity consumption $E_{p}$ during a day time. 
(a)

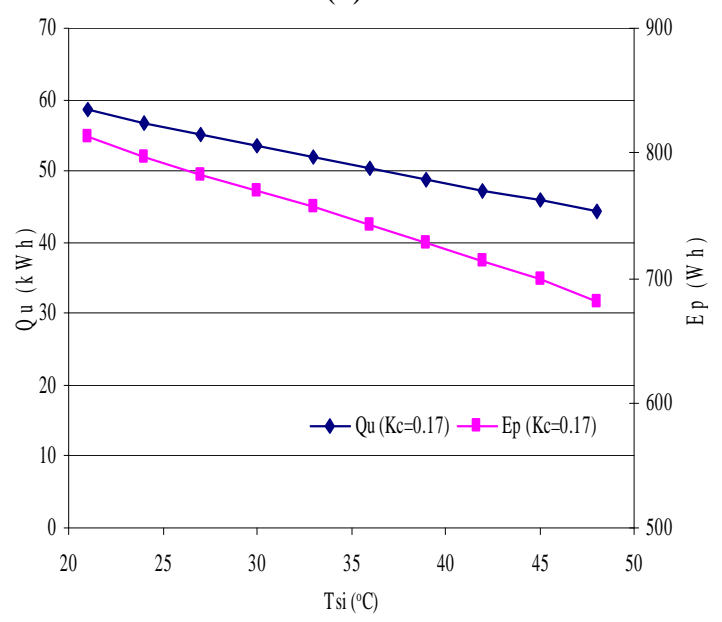

(h)

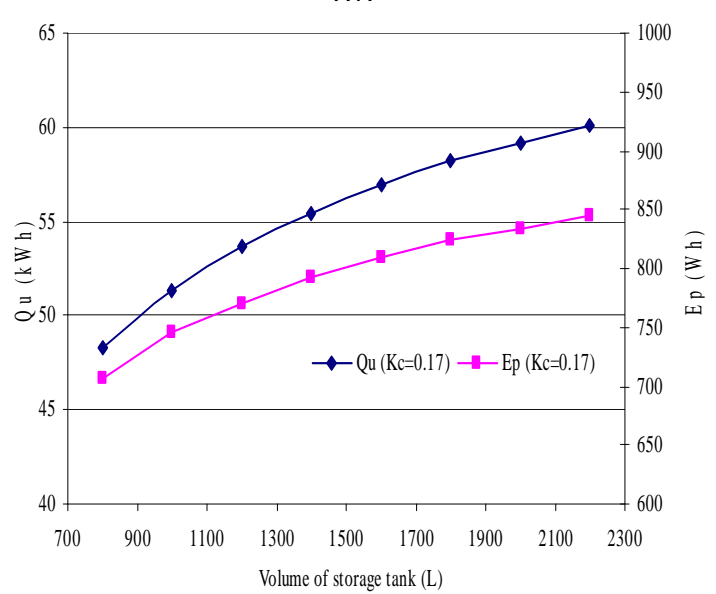

Fig. 7. (a) Effect the of initial water temperature in the storage tank on the useful heat gain $Q_{u}$ and electricity consumption $E_{p}$ during a day time; (b) effect of volume storage tank on the useful heat gain $Q_{u}$ and electricity consumption $E_{p}$ during a day time.

electricity consumption $E_{p}$, but at the forward coefficients of $K_{c}=0.17$, the amount of useful heat gain $Q_{u}$ increased slower than electricity consumption $E_{p}$. The system performance at $m=0.442 \mathrm{~kg} / \mathrm{s} \quad\left(\mathrm{K}_{\mathrm{c}}=0.17\right)$ higher than $1.33 \%$ compares with $m=0.364 \mathrm{~kg} / \mathrm{s} \quad\left(K_{c}=0.14\right)$ was proposed by [16]. Fig. 3 (b) shows the useful heat gain supplied to storage tank on the hour of the day. The amount of this the useful heat gain depends mainly on the temperature of water in the storage tank, ambient temperature and solar radiation.

Fig. 4 (a) and (b) shows mass flow rate variation during the hour of the day. The time operation of solar pump at the $m=0.364 \mathrm{~kg} / \mathrm{s}$ is longer than the $m=0.442 \mathrm{~kg} / \mathrm{s}$ on the hour of the day. Fig. 5 (a) shows temperature variation of water in storage tank on the hour of the day. At the end of day, the temperature of water in storage tank of $m=0.442 \mathrm{~kg} / \mathrm{s}$ higher than $0.45{ }^{\circ} \mathrm{C}$ compares with $m=0.364 \mathrm{~kg} / \mathrm{s}$ was proposed by [16] leads to higher heat loss (Fig. 5 (b)).
Fig. 6 (a) shows inlet and outlet water temperature of collector on the hour of the day. When the solar pump operated, the water temperature difference between inlet and outlet of the collector is $3{ }^{\circ} \mathrm{C}$ to $10^{\circ} \mathrm{C}$. Fig. 6 (b) shows the variations of the useful heat gain and electricity consumption of solar pump versus the collector areas. By increasing the collector areas leads to increase quickly the temperature of water in storage tank, then the useful heat gain increases but electricity consumption of pump decreases.

Fig. 7 (a) and (b) shows the effect of initial water temperature in the storage tank and the volume of storage tank on the useful heat gain and electricity consumption during a day time. By increasing the initial water temperature from $21^{\circ} \mathrm{C}$ to $48{ }^{\circ} \mathrm{C}$, the useful heat gain and electricity consumption decreases $24.4 \%$ and $16.3 \%$, respectively. While, increasing the volume of storage tank from $800 \mathrm{~L}$ to $2,200 \mathrm{~L}$, the useful heat gain and electricity consumption increases $22.6 \%$ and $18.1 \%$, respectively.

\section{Conclusions}

In this study, a mathematical model is developed to predict the operating performance of the solar domestic hot water system. The optimum mass flow rate through collector based on the relationship between the useful heat gain of solar collector and the electricity consumption of solar pump is investigated. The results of the simulation show that the system performance at $m=0.442 \mathrm{~kg} / \mathrm{s} \quad\left(\mathrm{K}_{\mathrm{c}}=0.17\right)$ higher than $1.33 \%$ compares with $m=0.364 \mathrm{~kg} / \mathrm{s} \quad\left(K_{c}=0.14\right)$ was proposed by [16]. It could also support the selection mass flow rate for the collector circuit of the solar domestic hot water system to be built. In addition, the variable of the collector areas, initial water temperatures and volume of storage tank significantly affected to the useful heat gain of solar collector and the electricity consumption of solar pump.

\section{Acknowledgement}

This work was supported by the Korea Institute of Energy Technology Evaluation and Planning (KETEP) grant funded by the Korea Government of MKE (No. 2010T100100709) and by the National Research Foundation of Korea (NRF) grant funded by the Korea Government of MEST (No. 20110012326).

\section{References}

[1] Duffie JA, Beckman WA. Solar engineering of thermal. $2^{\text {nd }}$ ed. New York: John Wiley and Sons; 1991.P.

[2] Kvarrik M, Lesse PF. Optimal control of flow in low temperature solar heat collector. Solar Energy 1976; 18(5):p. 431-5

[3] Winn CB, Hull DE, III. Optimal controllers of the second kind. Solar Energy 1979; 23: p.529-534 
[4] Dorato P, Jamshidi M. Some comments on collector of solar energy. Solar Energy 1982; 29(4):p.351-3

[5] Saltiel C, Sokolov M. Optimal control of a multicomponent solar collector system. Solar Energy 1985;34(6),p.463-473

[6] Beckman WA, Thornton J, Long S, Wood BD. Control problem in solar collector domestic hot water systems. Solar Energy 1994; 53(3),p.233-6

[7] BadescuV. Optimal control of flow in solar collector system with fully mixed water storage tanks. Energy Conversion\& Management 2008;49,p.169-184.

[8] Person T, Ronnelid M. Increasing solar gains by using hot water to heat dishwashers and washing machines. Applied Thermal Engineering 2007;p.646-657

[9] Furbo S, Shah LJ. Optimum solar collector fluid flow rates. Department of Buildings and Energy, Technical University of Denmark, proceedings of Eurosun 1996.

[10] Knudsen S. Consumers' influence on the thermal performance of small SDHW systems. Solar Energy 2002; 73(1),p.33-42

[11] Csordas CF, Brunger AP, Hollands KGT, Lighstone MF. Plume entrainment effects in solar domestic hot water systems Employing variable-flow-rate control strategies. Solar Energy 1992; 49(6),p. 497-505.

[12] Prapas DE, Veliannis I, Evangellopoulos A, Sotiropoulos BA. Large DHW solar systems with distributed storage tanks. Solar Energy 1995; 55(3),p.175-183.

[13] Kalogirou, Soteris. Solar energy engineering processes and systems. America, 2009

[14] Douglas R, Sun KK, Yong TK, Hiki H. Experimental verification of a solar hot water heating system with a spriraljacketed Storage tank. Mechanical Science and Technology 22(2008) 2228-2235.

[15] European simplified method for active solar system designe, Bernard Bourges, Kluwer Academic Publishers for CEC 1991.

[16] T Persson, M Ronnelid. Increasing solar gains by using hot water to heat dishwashers and washing machines. Applied Thermal Engineering 27(2007); p. 646-657. 